\title{
Lessons from the past in the present: news from the Spanish flu pandemic to COVID-19
}

\author{
Lições do passado no presente: notícias da pandemia de gripe espanhola à Covid-19 \\ Lecciones del pasado en el presente: noticias de la pandemia de gripe española al COVID-19
}

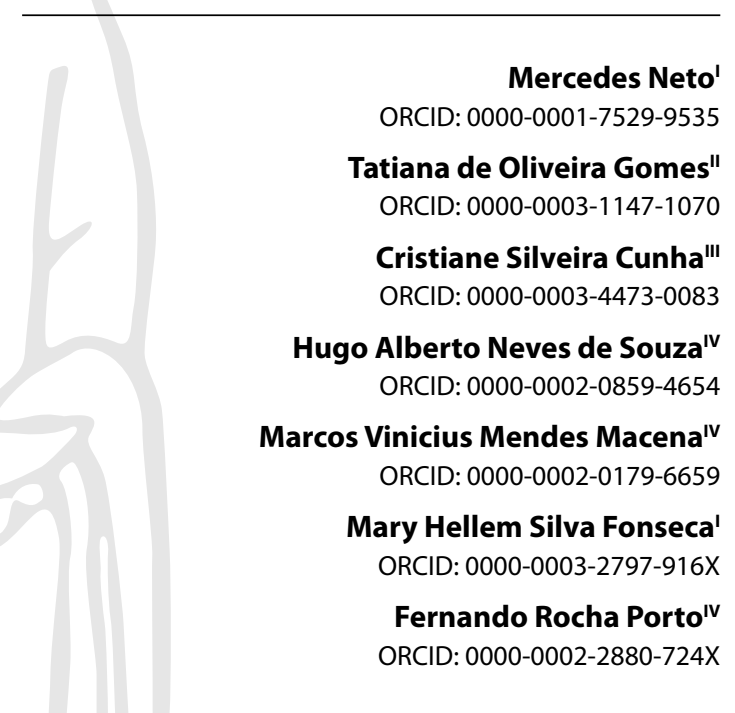

'Universidade do Estado do Rio de Janeiro. Rio de Janeiro, Rio de Janeiro, Brazil.

"Fundação Oswaldo Cruz. Rio de Janeiro, Rio de Janeiro, Brazil.

II'Centro Universitário de Volta Redonda. Rio de Janeiro, Rio de Janeiro, Brazil.

"Universidade Federal do Estado do Rio de Janeiro. Rio de Janeiro, Rio de Janeiro, Brazil.

How to cite this article:

Neto M, Gomes TO, Cunha CS, Souza HAN, Macena MVM, Fonseca MHS et al. Lessons from the past in the present: news from the Spanish flu pandemic to COVID-19. Rev Bras Enferm. 2022;75(1):e20201161. https://doi.org/10.1590/0034-7167-2020-1161

\section{Corresponding author:}

Mercedes Neto

E-mail: mercedesneto.uerj@gmail.com

EDITOR IN CHIEF: Dulce Barbosa ASSOCIATE EDITOR: Maria Itayra Padilha

\section{ABSTRACT}

Objective: to analyze the health conducts for combating the Spanish flu and its relationship with the COVID-19 pandemic in Rio de Janeiro. Methods: study from the perspective of microhistory, with analysis of articles published in Revista da Semana on the Spanish flu, having as criteria publications with the term "epidemic" referring to the Spanish flu or influenza in the period of the epidemic outbreak in Rio de Janeiro, Federal District. Results: 18 records, organized in three thematic axes: political, 4; social, 11; care, 3, were found. Final considerations: the lessons left by the Spanish flu epidemic in coronavirus times will be changes in the political, social and care field as marks of major epidemics.

Descriptors: Coronavirus Infections; Pandemics; News; Pandemic Influenza, 1918-1919; Nursing History.

\section{RESUMO}

Objetivo: analisar as condutas sanitárias para o combate da gripe espanhola e sua relação com a pandemia de COVID-19 no Rio de Janeiro. Métodos: estudo na perspectiva da microhistória, com análise de matérias publicadas na Revista da Semana sobre a gripe espanhola, tendo como critérios publicações com o termo "epidemia" referente à gripe espanhola ou à influenza no período do surto epidêmico e circunscrita no Rio de Janeiro, Distrito Federal. Resultados: foram encontrados 18 registros organizados em três eixos temáticos: político, 4; social, 11; de cuidados, 3. Considerações finais: as lições deixadas pela epidemia da gripe espanhola em tempos de coronavírus serão de mudanças no campo político, social e dos cuidados como marcas das grandes epidemias.

Descritores: Infecções por Coronavírus; Pandemias; Notícias; Influenza Pandêmica, 19181919; História da Enfermagem.

\section{RESUMEN}

Objetivo: analizar la conducta sanitaria para combatir la gripe española y su relación con la pandemia COVID-19 en Río de Janeiro. Métodos: estudio desde la perspectiva de la microhistoria, con análisis de los artículos publicados en la Revista da Semana sobre la gripe española, utilizando como criterio las publicaciones con el término "epidemia" referida a la gripe española o influenza en el período de la epidemia y brote circunscrito en Río de Janeiro, Distrito Federal. Resultados: se encontraron 18 registros organizados en tres ejes temáticos: político, 4; social, 11; de atención, 3. Consideraciones finales: las lecciones dejadas por la epidemia de gripe española en tiempos de coronavirus serán los cambios en el ámbito político, social y asistencial como marcas de las grandes epidemias.

Descriptores: Infecciones por Coronavirus; Pandemias; Notícias; Influenza Pandémica, 1918-1919; Historia de la Enfermería. 


\section{INTRODUCTION}

102 years ago, Brazil was hit by the Spanish flu pandemic in the context after World War I. At the time, it is known that the scourge entered the country by the ship Demerara, departing from Liverpool to Recife. Due to many days of travel, several deaths occurred. With the arrival of transport to the port, a flag that signaled the quarantine was flown, but Brazilian medical authorities thought the conduct was premature, because it was a simple flu. From then on, the disease spread and plagued the rest of the country. In this perspective, the context disorganized in the political, social, economic and health field with the closure/ standstill of ports, transport and several other services ${ }^{(1)}$.

In health institutions, those affected arrived with viral pneumonia, bleeding, vomiting and chills. The care provided was hot baths, offer of a diet based on wines and hominy grits, as well as medication administration such as quinine and purgatives, enhanced with the advertising of pills and quinine water, with the promise of curing the disease ${ }^{(2-5)}$. Moreover, there was a lack of protective material for health professionals, as well as the lack of knowledge of the genetics of the virus ${ }^{(1)}$.

Many people died, both in health institutions and in their own households $s^{(1)}$, one of them being the President of Brazil, Rodrigues Alves, when, in the current voice, the Spanish flu in the country became known as a democratic disease.

Government authorities struggled to establish quarantine and close borders to reduce the virus circulation. However, measures were taken to prevent prevention to avoid public criticism and reassure the population ${ }^{(1)}$.

This pandemic scenario in the past times reminds the present time, with the new disease caused by a new type of coronavirus, COVID-19, which refers to the question: what are the lessons left by the Spanish flu for the current pandemic of COVID-19?

Therefore, to justify the relevance of this article may seem redundant, but it is necessary to bring to memory the historiography of major epidemics and remember that they examine the epidemiological ruptures, which have shaken the social, economic, cultural, political and demographic structures ${ }^{(6)}$. Thinking about this perspective, in this moment of pandemic, is what makes us investigate the lessons left for the present time.

\section{OBJECTIVE}

To analyze the health conducts for combating the Spanish flu and its relationship with the COVID-19 pandemic in Rio de Janeiro.

\section{METHOD}

\section{Ethical aspects}

This study was not submitted to an Institutional Review Board, as the sources are public ${ }^{(7)}$.

\section{Theoretical-methodological framework}

Microanalysis was the methodological framework ${ }^{(8)}$, which verifies the phenomenon in the micro sense, when dialoguing with the macro aspects. In other words, in a metaphor's tone, it is to know the ocean by a drop of water.

\section{Type of study}

This is a qualitative research from the perspective of microhistory, carried out from an analysis of facsimiles that make up Revista da Semana, based on Carlo Ginzburg's theoretical framework ${ }^{(9)}$.

\section{Data source}

The sources for the construction of this research were articles published in Revista da Semana, at the time of the Spanish flu, through the term "epidemic". This was chosen because it was the first journal to publish photographic images - facsimiles - which reconfigured the press with its creation in 1900. Moreover, it was the most read for its light reading feature for women ${ }^{(10)}$.

The inclusion criteria used were: temporal delimitation from 1918 to 1919 , publications with the term "epidemic" referring to Spanish influenza or influenza, during the epidemic outbreak and circumscribed in Rio de Janeiro, Federal District. Exclusion criteria were: news of deceased people/obituaries, records of any problem in the press and text with historical perspectives of times gone by the uninvestigated phenomenon.

\section{Data collection and organization}

Data collection occurred in April 2020 in the digital Brazilian National Library through a collection instrument, composed of dating, editing, page, article title and synthesis of the news record, which gave rise to thematic axes by approximation for analysis of results. It is worth noting that the Recommendations Standards for Reporting Qualitative Research (SRQR) were followed.

\section{Data analysis}

Through the results found, data were organized in thematic axes for analysis based on literature adherence, aiming at achieving the objective. Subsequently, the final considerations were conducted when the lessons left by the Spanish flu for the COVID-19 pandemic were pointed out.

\section{RESULTS}

In the search for news records in Revista da Semana, 36 occurrences were identified with the term "epidemic" in the proposed temporal delimitation. However, when applying the established criteria, 18 news records were obtained from October 18 to November 16, 1918, common in the methodological framework's proposal and understood as the reduction of temporal delimitation.

After data organization, three thematic axes were established: political, totaling 4 news records; totaling 11 records; with a total of 3. The first axis was aimed at political aspects, gathering the issues related to the country's rulers and scientists in the fight to combat the Spanish flu; the second was related to case reports, conditions in the city of Rio de Janeiro and quantification of deaths; the third grouped the recommended care for prevention and fight against influenza. 
Chart 1 - The term "epidemic" of influenza in the news records in Revista da Semana and thematic grouping (October 19 to November 16, 1918), Rio de Janeiro, Brazil

\begin{tabular}{|c|c|c|c|}
\hline Date & Article title & Summary of news record & $\begin{array}{l}\text { Thematic } \\
\text { axes }\end{array}$ \\
\hline 10/19/1918 & A epidemia (The epidemic) & $\begin{array}{l}\text { Political crisis lacks measures, resulting in paralyzing various sectors in } \\
\text { society. }\end{array}$ & Political \\
\hline 10/19/1918 & $\begin{array}{l}\text { Consultório de Mulher-Influenza Hespanhola (Women's } \\
\text { Office-Influenza Hespanhola) }\end{array}$ & Advice on body hygiene and environments. & Care \\
\hline \multirow{7}{*}{$10 / 26 / 1918$} & A epidemia (The epidemic) & Worsening of the epidemic by not having heard the voice of science. & Political \\
\hline & Cartas de Mulheres (Letters from Women) & $\begin{array}{l}\text { She reports the passage of a worker affected by influenza, but for fear of } \\
\text { losing her job she continued her work activities and after days she died. }\end{array}$ & Social \\
\hline & $\begin{array}{l}\text { A epidemia - para combater e debelar a influenza- } \\
\text { conselhos prevenções e remédios (The epidemic - to fight } \\
\text { and stop influenza - prevention advice and medicines) }\end{array}$ & $\begin{array}{l}\text { Infected registry should be isolated and presents prevention, combat } \\
\text { and care with older adults. }\end{array}$ & Care \\
\hline & $\begin{array}{l}\text { Notícias e comentários Aspectos macabros do Rio durante } \\
\text { a epidemia (News and comments Macabre aspects of } \\
\text { Rio during the epidemic) }\end{array}$ & They report as prophylactic purgative therapy and diets. & Care \\
\hline & Os marinheiros de Pittsburgh (The Sailors of Pittsburgh) & Death record of 26 sailors, meaning $10 \%$ of the crew. & Social \\
\hline & $\begin{array}{l}\text { A estatística fúnebre da epidemia (The mournful statistics } \\
\text { of the epidemic) }\end{array}$ & Records the number of deaths, leading to overcrowding in cemeteries. & Social \\
\hline & A semana trágica (The tragic week) & Reports the death of 30 doctors and medical students. & Social \\
\hline \multirow{4}{*}{$11 / 02 / 1918$} & $\begin{array}{l}\text { Cartas de mulheres - o amor trágico (Letters from } \\
\text { women - tragic love) }\end{array}$ & It reports the case of an infected husband who committed suicide. & Social \\
\hline & $\begin{array}{l}\text { A hecatombe da epidemia (The hecatomb of the } \\
\text { epidemic) }\end{array}$ & $\begin{array}{l}\text { Records the number of fatal victims, and the epidemic is without } \\
\text { social criteria }\end{array}$ & Social \\
\hline & $\begin{array}{l}\text { Carlos Chagas e a epidemia (Carlos Chagas and the } \\
\text { epidemic) }\end{array}$ & It records the contribution of scientist Carlos Chagas to the epidemic. & Political \\
\hline & $\begin{array}{l}\text { Semana elegante - A cidade triste (Elegant week - The } \\
\text { sad city) }\end{array}$ & It reports the sad and empty city, with few people on the streets. & Social \\
\hline \multirow{2}{*}{$11 / 09 / 1918$} & Cartas de mulheres (Women's letters) & $\begin{array}{l}\text { It reports suffering and the ability to overcome them, highlighting the } \\
\text { pain of mothers for the loss of their children. }\end{array}$ & Social \\
\hline & A epidemia e os presidiários (The epidemic and inmates) & $\begin{array}{l}\text { It reports penitentiary's poor conditions and the contribution of } \\
\text { inmates in the burials. }\end{array}$ & Social \\
\hline \multirow[t]{2}{*}{$11 / 16 / 1918$} & $\begin{array}{l}\text { O sr. Rodrigues Alves não a presidência (Mr. Rodrigues } \\
\text { Alves not to presidency) }\end{array}$ & Records the loss of Mr. Rodrigues Alves - as president of Brazil. & Political \\
\hline & Uma heroína da Caridade (A heroine of Charity) & It cites selfless religious and solidarity to those in need. & Social \\
\hline
\end{tabular}

\section{DISCUSSION}

The Spanish flu, dated 1918, originated in the United States of America in the post-war period, but was named after Spain being the first country to report that several soldiers had to leave the front after presenting viral symptoms, in addition to the record of deaths due to pneumonia. Thus, there was the false impression that Spain was the most affected country, or that the flu would have originated there ${ }^{(11)}$.

In present times, specifically in December 2019, individuals were affected by fatal pneumonia, originated in the city of Wuhan (China), caused by a new type of coronavirus identified as Severe Acute Respiratory Syndrome Coronavirus 2 (SARS-CoV-2), which resulted in a disease called by the World Health Organization as Coronavirus Disease (COVID-19) ${ }^{(12-13)}$.

Such pandemic contexts, past and present, directed this study to understanding in the micro sense and by likelihood by the slowness of Revista da Semana, the care and events surrounding the Spanish flu.

\section{Spanish flu pandemic}

In the axis of politics, the records identified were news published involving those named, nominally, Carlos Seidl, Carlos Chagas and Rodrigues Alves.

As mentioned in the articles, Carlos Seidl, Director General of Public Health, equivalent to the Minister of Health currently, did not take the necessary steps for preventing the Spanish flu, because he did not believe that the disease would advance, considering isolation unfeasible. The justification was supported by the argumentation of the effect of economy decline due to reduction of people in the labor market, the means of transport and the interruption of the operation of colleges and theaters ${ }^{(14)}$.

Another argument presented in the news records was the fact that the government authorities devalued the scientific notes regarding the potentiation of the contagion ${ }^{(14)}$, which indicated the Spanish flu pandemic as a fatal clinical picture in the course of 3 days, damaging the upper respiratory tract and digestive tract, returning attention, especially, to countryside cities of Rio de Janeiro State. 
Understanding what happened in the past with Carlos Seidl, through journals, such as A Noite and A Gazeta de Notícias, makes it possible to observe that the criticisms received by him contributed to its wear and tear with the people, motivated by the fear of death, by the lack of performance of health services, in addition to the disorganization of daily life ${ }^{(14)}$, as well as by the assertion of the lack of contribution of science by not constituting itself as an area of knowledge ${ }^{(15)}$.

Moreover, it is noteworthy that Seidl was severely criticized for journalistic articles, as well as for the policy in force at the time, during the administration of Venceslau Brás. With the crisis installed, Carlos Chagas' name was then appointed to take over the General Directorate of Public Health, replacing Seidl ${ }^{(13)}$. It is emphasized that the appointment occurred due to the studies developed by him with the discovery of Tripanosoma cruzi, a pathogen causing Chagas disease, in the presidential administration of Venceslau Brás (1914-1918), which had the effect of winning several titles and awards, giving him credibility as a renowned scientist ${ }^{(14)}$.

The news records collected on economic aspects were transversal, with a strong indication of effect on the social axis, highlighting aspects about work, private and social life, solidarity and movement in cemeteries. It is possible to identify, in the micro sense, concerns about the maintenance of employment by the employee, the lack of food in the trade and the silence of the city, which, consequently, decreased the circulation of current currency.

Among the news records presented to the readers of Revista da Semana, they had descriptions of how a person continued to work, even with signs and symptoms, such as pallor, weakening and fever, for fear of losing the family's livelihood and eventually died. On the other hand, there is news of a contaminated family provider who, for fear of transmitting the disease to their family, chose to end their own life. Furthermore, it is noteworthy that, at the time, when the gravediggers identified bodies with signs of breathing, they eliminated them with the shovels used for burial ${ }^{(16)}$.

The epidemic moment, imposed by the Spanish flu, was of abrupt ruptures, imposing feelings and emotions permeated with the effect of sadness. This reinforced the arguments of destructuring in the face of the situation, i.e., a reflection of the whole by the part of people's lives. To get an idea, we know that many deaths occurred in the age group of 20 to 45 years, especially among those with heart and tuberculous diseases, including also those living in conditions of social and biological deficiency ${ }^{(14)}$.

As we can identify, Revista da Semana, like other journals, produced a sense of representation of the common scenario lived to be consumed by readers with the possible truths that would remain in the memories and would be passed on to future generations, signaling the culture of safety and risk ${ }^{(17)}$.

Safety culture was the isolation that nourished hope for the now, at that time, and tomorrow, in the sense of the future, which was opposed to the culture of risk that emphasized the dangers of progress with difficult solution by the idea of representation of the apocalypse before the dark contours led by the media production of that time ${ }^{(17)}$.

Another record found was reports of penitentiaries' poor conditions in Rio de Janeiro. To alleviate the situation of some inmates, they were destined to collaborate with grave preparation, due to the cluster of dead who needed burial. This data is possible for ratification, considering the number of dead, without the rites as wake and burial, when workers'labor force was used. However, it was still possible to see clusters of bodies through the deserted streets ${ }^{(16)}$. This cost the lives of inmates, a strategy used to mitigate the criticism softened at the time, giving the idea of contribution/collaboration of those who lived in precarious conditions instituted by the State.

In the midst of this scenario of fear and loss, Revista da Semana brings, from a social perspective, the solidarity provided by a religious. It, with the mission of bringing to those in need some material and spiritual comfort, was considered the saint of the hills and the saddles, giving evidence to mercy for the solidarity provided to those most in need, which made the press shed light on the attitude taken.

Solidarity in news records is articulated to the religious aspect published by Revista da Semana, which, at first glance, may show warmth, sociocultural attitude, but also dispute groups in establishing models. It is the commitment that each individual feel and force to have through each other, which is salutary, but also covered with moral varnish by the "(in)visible" interests to obtain the expected effect.

In relation to the news of a religious who climbed a hill to help those most in need, the media highlight puts credibility on human solidarity without forgetting the dogmas of mercy, here delimited in the body, namely: to feed the hungry, give drink to those who are based, give inn to pilgrims, dress the naked, visit the sick, visit inmates and bury the dead ${ }^{(18-19)}$ when the culture of risk competes with that of safety.

Thus, thinking about the lives of these people reminds us of the work "Memórias de Nelson Rodrigues". There are reports about what the plague pandemic left those who managed to survive - fear, amazement, resentment and the fear of death ${ }^{(18-19)}$. This applies to All Souls' Day, at that time, in Rio de Janeiro, when flowers, instead of cheering the city, served for the farewell of loved ones. It was in this scenario of suffering of private life, articulated to solidarity, that the record of the city, in silence, empty and sad was represented in the period when the Spanish flu was on the population.

In this context of fear, sadness and horror, the news record disclosed the total number of fatalities $(10,000)$, with details of the days (20, 21 and 22 October) with thousands of deaths, resulting in burials that took place in agglomerated form due to the lack of prepared pits, taking bodies to be deposited in mass graves or, when not, had to wait for hours and days, to the point of having coffins in the middle of public roads. Here, the so-called relevance of the contribution of inmates who have had their social debts paid with their lives is taken up.

With the cemeteries full of bodies to be buried and the representation of the Pro-Health League of Brazil (Liga Pró-Saneamento do Brasil) (1918-1920), it was led by Belisário Penna, a physician from Bahia State, who arrived in Rio de Janeiro in 1904, working in the General Directorate of Public Health and is the author of Saneamento do Brasil (1918). Considering the country as a large hospital, the need to reconfiguration social policies in Brazil was reinforced, which, articulated to the leadership of Carlos Chagas, in the fight against the Spanish flu, took strength and materiality in the 1920s, with the Health Reform he led. Therefore, in this perspective, the transformation of spaces into a large cemetery by the Spanish flu allowed new ways to legitimize the prestige of scientific and political power ${ }^{(14)}$. 
The last axis identified was called care, which presented news records from hygienic care, food, so-called non-scientific therapies, to the isolation that also permeates the political and social axes in favor of combating the Spanish flu.

With regard to the records, such as sleeping with open windows, breathing fresh air leaving the residence ventilated, disinfecting the mouth and nostrils and cleaning the intestines can translate disease prevention actions at the time. Care in washing hands and nostrils was justified to avoid contamination when touching the face. Moreover, in cases of presentation of some Spanish flu symptoms, patients should stay in their residence and remain isolated in one of the rooms without receiving a visit, with a double attention to older adults.

For the throat, the recommendation was the use of salt water or diluted oxygenated water, in order to eliminate some pathological agent, making an argument that hygienic care was necessary due to the ignorance of preventive drugs or specific vaccines. As the doctors did not know how to treat the scourge, the foods prescribed were chicken and lemon broth, including quinine-based substances. On the other hand, there was a lack of food, with warehouses being looted, generating panic and despair, which confirmed the reconfiguration of public health ${ }^{(16)}$.

The records highlighted non-scientific therapies, with combinations of substances, with an argument for the absence of specific healing drugs and the absence of immunization by scientists at that time. As preventive care, the recommendation was to wash the mouth with indicated saltwater solutions, in proportion of one tablespoon of salt to 1 liter of boiled water, and may contain cinnamon essence; inhalation of mentholated petroleum jelly with iodized water, plus citric acid and tannin; infusions of guava leaves (tea); use of any substance with quinine salt, preferably during meals. Additionally, the use of several purgatives was another preventive recommendation. As a treatment, for cases of fever, the recommendation was a solution of a coffee spoon in half a glass of sugary water every two hours until the symptom disappeared.

In the care axis, isolation was destined to the contaminated that should be destined to hospitals, colleges and hospices, under the logic of isolating patients as a precautionary strategy for preventing the disease to spread among people. Another conduct adopted was related to social etiquette. The incentive was to inhibit handshakes, kisses at your fingertips in sociocultural life, as well as not visiting the sick. The "new" norm and/or sociocultural rule was recommended, especially since it was recorded that $1 / 3$ of the population of Rio de Janeiro was affected and that it had landed in the Port of city sailors of Pittsburgh, resulting in $10 \%$ of the crew falling ill.

Isolating patients and disinfecting ships and baggage were conducts adopted directly and/or indirectly, found in other studies ${ }^{(14-15)}$. In other words, isolation and hygienic care were fundamental to try to reduce transmission, so much so that the orientation was that the population would not crowd, especially in the face of the panic already instituted when barracks, factories and schools had already been hit, making the city a chaos ${ }^{(16)}$.

Late October 1918, sadness, fear and horror haunted the city. The closure of public institutions, commerce and industry paralyzed the city. One of the strategies adopted by the rulers was the distribution of quinine both to prevent the spread and treatment, but without knowing the validity and scientific therapeutic efficacy, in fact, of the fight against the virus that affected the population ${ }^{(16)}$.

In this logic, patient care, when scientifically proven, is now called treatment ${ }^{(20)}$. This implies what is meant about epistemic reconfiguration, i.e., when the practice is tested, evaluated and revalidated by scientific knowledge, care is understood as therapeutic or treatment.

\section{COVID-19 pandemic}

Recalling that analysis was conducted by 3 thematic axes, some lessons for the COVID-19 times present their arguments, mostly through interviews, which point to reflections towards the construction of the historical narrative of the present time in relation to the period of the Spanish flu.

One of the lessons that the Spanish flu pandemic leaves in COVID-19 times is the possibility of being able to think about changes in the Federal, State and Municipal spheres, considering the problems of basic sanitation, especially water and sewage, in housing and public roads ${ }^{(21)}$. It approaches, within its limitations, the conditions encountered by the Spanish flu in Rio de Janeiro when it affects the population in the mansions, a space of agglomeration of people without the basic conditions to live.

At the time of the Spanish flu, the crisis in public health was evident for several aspects that were analyzed. In coronavirus times, when the Brazilian Unified Health System (SUS - Sistema Único de Saúde) shows its effectiveness and efficiency, some politicians try to polemize the subject without argumentative support, which currently makes us understand that, in the crisis, SUS becomes a reference in actions to prevent and combat those affected by the new epidemic ${ }^{(21)}$.

Science, both in the time of the Spanish flu and in coronavirus times, has been/is put in check to respond to the demands of public health by the bias of politics. This implies global challenges, with articulation of sociocultural, political and economic dimensions to equate challenges by their complexity in the sense of interrelationship and integrality, which points to a more recent period in the history of the planet, understood as Anthropocene ${ }^{(22)}$. This fact shows that the demands are interconnected, because we all live in the same macro geographical space, mother earth.

Thinking about the perspective of the economy in any period of pandemic in history is a concern that needs to be scored. At the time of the Spanish flu, according to the records consulted, we did not identify social isolation as currently, but the controversy of the economy does. Nowadays, social isolation seems to be the discord of the economy with health, while the majority thought should be human life. In this sense, some governments need to think of a certain economic downturn, by contrary to the guidelines of epidemiologists, national and international on social isolation, especially for those older and with other diseases ${ }^{(13,23)}$. This points us to the point that we need to think beyond them, in the sense of those who live with those who are considered belonging to the risk group.

Discussion put, it is worth knowing the arguments of each segment. On the one hand, health experts claim that isolation is the possibility of mitigating transmission; on the other hand, experts on the subject of economics claim that isolation paralyzes the financial sector, which would unduly harm economic development and that post-pandemic returns would be compromised by the 
country's currencies ${ }^{(23)}$. Open debate arena, it is up to us to think not what is worth more, but that economic production depends directly on the human being, which makes us reflect that, without them and for them, the economy lacks meaning production. In this perspective, maintaining preventive measures of social isolation is to reduce the mortality rate, as well as mitigate the economic impact that the epidemic can have on the country's financial sector ${ }^{(23)}$.

The Spanish flu has had an economic impact on the world. In Philadelphia, for example, the mortality rate was considerable, but interventions in the health field have resulted in alleviating them. The industry and banking sector recover when data on the duration of measures during the Spanish flu and the mortality rate are crossed, which resulted in satisfactory post-epidemic economic indicators ${ }^{(23)}$.

In summary, on the social aspect during the Spanish flu, we had the opportunity to identify that the news records had, in effect, the feeling of fear, for instance. By drawing a parallel with the dramatic impact of the disease and isolation guidelines, the period was marked by antagonistic behaviors and feelings of fear of death and the joy of being alive. At the time, the understanding was that it was the end times. Therefore, people did not respect isolation guidelines, as people took to the streets ${ }^{(24)}$.

Nowadays, people want to leave home under the argument that they need to work, because, unlike the past, today, with the advent of the Internet, they can communicate beyond the voice, with the image. They have private "parties" with the isolated members at home, but miss the personal conviviality, even in the face of new rules and/or social norms.

At the time, in Rio de Janeiro, news records report that the population was forced to comply with some determinations, because two-thirds were bedridden, totaling about 15,000 dead $^{(14,24)}$. The data found in this research converge by the above, when, for example, the recommendation was not to visit patients and avoid kissing and agglomerations.

The data analyzed in the social aspect, through Revista da Semana, report a sad and silent city, beyond All Souls' Day. This data of the social space with sepulchral air is also pointed out in other studies, evidenced during the Spanish flu, such as the emptying of public spaces, funeral air and unusual silence, because people began to get sick; therefore, traffic was drastically reduced. However, in November 1918, after 30 days, the epidemic was controlled in the city ${ }^{(24)}$. Since, also, we verified during reading the news records, although it does not meet the inclusion criteria for analysis of results.

Nowadays, coronavirus times, with social isolation, domestic life, has become everyday as a measure to tackle the pandemic. On the other hand, political and social discord occupies the media agendas; when racers in favor of social anti-isolation, led by some entrepreneurs, claim the return to work of employees, bearing in case that they need to work and the economy of the country cannot stop ${ }^{(25)}$. The political and social aspects in the past and present are evident, even in distant contexts in time and sociocultural space, but close in the circumstances of an epidemic.

Epidemics, in general, directly interfere in relationships by provoking a feeling of solidarity and selfishness. Entrepreneurs choose to defend their interests, while, in the private sphere of their homes, they take care to avoid contamination, isolating themselves when affected by the disease ${ }^{(25)}$. The employees, when affected, work until they can no longer, as presented the news record about the seamstress who worked until death so as not to have to live on the hill. This points us to versions and interpretations that depend on which side the situation occurs and what level of commitment each one by virtue of their interests.

This fact is ratified when researchers of the present time report in recent interviews (2020) that the COVID-19 pandemic is much more threatening to the poor and vulnerable, which carries the memory full of meanings that need to be unveiled ${ }^{(26)}$. This is consistent with the data found in this research, even in the micro sense, because the macro projection, at the time, can be done and so is found in the discussion. The elementary structures in the social aspect sometimes show that the lessons left by the past find in the human being a certain difficulty to be learned.

With regard to care during the Spanish flu, we find conducts, recipes and recommendations from various aspects. In coronavirus times, some recommendations, recipes and conducts circulate on the internet, promising "miracles", but without scientific proof, currently called fake news. They became another type of epidemic, in the figurative sense ${ }^{(24)}$

At the time of the Spanish flu, recipes, conducts and recommendations also circulated in the press. This fact was possible to identify, in the findings of this research, a promise of cure or prevention against the disease virus, and it should be noted that some were signed by professionals in the field of medicine. This phenomenon, in 1918, was attributed to the Carioca press in the so-called "peculiar recipes"(24).

When mentioned recipes, conducts and recommendations, include food aspects, such as eating chicken meat, soup, milk, rice, lentils and oats, data found in this research. This was not different in other studies on the recommendation of such foods, even expanding to chicken broth, eggs and lemon, considered miraculous, regardless of scientific evidence, which caused a certain impact on the emotional sense, mainly because they seemed to be ratified when distributed by the government. If, in the $14^{\text {th }}$ and $17^{\text {th }}$ centuries, when the black plague affected the population in Europe, the "rumors" were verbal, in the Spanish flu, it happened in the written and illustrated press ${ }^{(24)}$.

In COVID-19 times, fake news occurs via social networks, which can be identified in the past and present. There is several typification of news records with the theme of pandemic disease today, which brings information related to the discourses of health authorities, prevention measures, disease prognosis, therapy and vaccination. Such news may modify self-care behaviors, but also put at risk the health model in force in SUS ${ }^{(27)}$.

\section{Study limitations}

One of the limitations is found in the path of the Spanish flu in the post-epidemic of times not experienced by us, vision, perception and feelings, unlike the COVID-19 epidemic.

\section{Contributions to nursing and health}

To think about the contribution to nursing and health is to understand the ethos of care, which brings to the reflection that, even without the news record with the word, it is paramount to ensure life and rule out death ${ }^{(19)}$. 


\section{FINAL CONSIDERATIONS}

The lessons left by the Spanish flu epidemic in coronavirus times have been diluted in the political, social and care aspects. The possibility of changes/adjustments in the field of politics, especially in health, considering the knowledge of science, and the direct relationship of the economy with health are in line with the feelings of fear, dread and horror, which are destabilizing in a public health emergency.

Washing hands is an educational action to prevent contamination, but complex, due to lack of basic sanitation, which persists as an implication of this action. Social isolation is another safety action to avoid transmission, but complex, even in social network times, especially considering that this is not for everyone. Also, health information with several fake news regarding the recommendations and miraculous popular behaviors, not going against the success to combat phenomena such as an epidemic.

Finally, some reflections made possible by the past, reproduced in the present, which demonstrate the cyclical form that history presents, which, with rereading of positions and conducts, is a potential generator of learning for nursing and binder of scientific knowledge in coping with pandemics.

\section{REFERENCES}

1. Fioravanti C. Semelhanças entre a gripe espanhola e a COVID-19. Rev Pesqui FAPESP [Internet]. 2020. [cited 2020 Apr 15]. Available from: https://revistapesquisa.fapesp.br/2020/03/26/semelhancas-entre-a-gripe-espanhola-e-a-CoVid-19/

2. Neto M, Porto F. O que o passado tem a nos ensinar sobre a influenza? Rev Enferm UERJ [Internet]. 2019 [cited 2020 Apr 15]; 27 (1):e40236. https://doi.org/10.12957/reuerj.2019.40236

3. Black M, Armstrong P. An introduction to avian and pandemic influenza. NSW Public Health Bull [Internet]. 2006 [cited 2020 Apr 17];17 (78):99-103. https://doi.org/10.1071/nb06024

4. Oppermann A. Gripes históricas: a história das gripes. Textos Especiais. Rev Avent Hist [Internet]. 2009 [cited 2020 Apr 15];71(1):1-2; Available from: https://historiablog.org/2009/09/04/gripes-historicas-a-historia-das-gripes/

5. Cheng KF, Leung PV. What happened in China during the 1918 influenza pandemic? Int J Infect Dis. [Internet]. 2007 [cited 2020 Apr 17];11(4):360-4. https://doi.org/10.1016/j.ijid.2006.07.009

6. Santos LAC. Um Século de Cólera: Itinerário do Medo. Physis - Rev Saúde Coletiva [Internet]. 1994 [cited 2020 Apr 22];4(1). Available from: http://www.scielo.br/pdf/physis/v4n1/05.pdf

7. Congresso Nacional (BR). Lei no 9.610, de 19 de fevereiro de 1998. Altera, atualiza e consolida a legislação sobre direitos autorais e dá outras providências. [Internet]. 1998 [cited 2020 Apr 21]. Available from: http://www.planalto.gov.br/ccivil_03/leis/l9610.htm

8. Revel J. Micro-história, macro-história: o que as variações de escala ajudam a pensar em um mundo globalizado. Rev Bras Educ [Internet]. 2010 [cited 2020 Apr 22];5(45):434-44. https://doi.org/10.1590/S1413-24782010000300003

9. Ginzburg C. A micro-história e outros ensaios. Lisboa/Rio de Janeiro: Difel Bertrand Brasil; 1991. 235p.

10. Mauad A. Na mira do olhar: um exercício de análise da fotografia nas revistas ilustradas cariocas, na primeira metade do século XX. Anais Museu Paulista: Hist Cul Mat [Internet] 2005 [cited 2020 Apr 22];13(1):133-174. https://doi.org/10.1590/S0101-47142005000100005

11. Tsoucalas G, Kousoulis A, Sgantzos M. The 1918 Spanish Flu Pandemic: the origins of the H1N1 virus starin, a glance in history. Eur. J.Cl. Biom. Scienc [Internet]. 2016 [cited 2020 Apr 22];2(4):23-28. https://doi.org/10.11648/j.ejcbs.20160204.11

12. Ministério da Saúde (BR). Diretrizes para diagnóstico e tratamento da COVID-19. Brasília. 2020. [Internet]. 2020. [cited 2020 Apr 23]. Available from: https://portalarquivos.saude.gov.br/images/pdf/2020/April/07/ddt-covid-19.pdf

13. Belasco AGS, Fonseca CD. Coronavírus 2020. Rev Bras Enferm [Internet]. 2020 [cited 2020 Apr 20];73(2):e2020n2. https://doi. org/10.1590/0034-7167-2020730201

14. Goulart AC. Revisitando a espanhola: a gripe pandêmica de 1918 no Rio de Janeiro. Hist Cienc Saúde -Manguinhos. [Internet] 2005 [cited 2020 Apr 20];12(1). https://doi.org/10.1590/S0104-59702005000100006

15. Brito NA. La dançarina: a gripe espanhola e o cotidiano na cidade do Rio de Janeiro. Hist. cienc. saude-Manguinhos. [Internet] 1997 [cited 2020 Apr 20];4(1):11-30. https://doi.org/10.1590/S0104-59701997000100002

16. Cuidado com a'Espanhola'! Blog de História, Ciências, Saúde - Manguinhos[Internet]. 2015 [cited 2020 Mar 28]. Available from: http://www. revistahcsm.coc.fiocruz.br/cuidado-com-a-espanhola

17. Bertolli Filho C. Novas doenças, velhos medos: a mídia e as projeções um futuro apocalítico. In: Monteiro, YN, Carneiro MLT, organizadores. As doenças e os medos sociais. São Paulo: Editora Fasp-Unifesp; 2012. p. 30.

18. Morais N. Doença e medo: charges, sentidos e poder na sociedade midiática. In: Monteiro, YN, Carneiro MLT, organizadores. As doenças e os medos sociais. São Paulo: Editora Fasp-Unifesp; 2012. p. 28.

19. Rodrigues N. Memórias de Nelson Rodrigues. Rio de Janeiro: Ed. Correio da Manhã; 1967.

20. Colliére MF. Cuidar: a primeira arte da vida. Loures: Lusociência; 2003.

21. Sanglard G, Costa RGR. Oswaldo Cruz no combate às epidemias. Blog de História, Ciências, Saúde - Manguinhos[Internet]. 2020. [cited 2020 Apr 21]. Available from: http://www.revistahcsm.coc.fiocruz.br/oswaldo-cruz-no-combate-as-epidemias/ 
22. Silva AFC, Lopes G. A pandemia de coronavírus e o Antropoceno. Blog de História, Ciências, Saúde - Manguinhos [Internet]. 2020. [cited $2020 \mathrm{Apr}$ 21]. Available from: http://www.revistahcsm.coc.fiocruz.br/a-pandemia-de-coronavirus-e-o-antropoceno/

23. Schreiber M. Cidades dos EUA que usaram isolamento social contra gripe espanhola tiveram recuperação econômica mais rápida. BBC News Brasil [Internet]. 2020. [cited 2020 Apr 12] Available from: https://www.bbc.com/portuguese/internacional-52075870

24. Albuquerque C. Fake news circularam na imprensa na epidemia de 1918. Blog de História, Ciências, Saúde - Manguinhos. [Internet]. 2020 [cited 2020 Apr 21]. Available from: http://www.revistahcsm.coc.fiocruz.br/ fake-news-circularam-na-imprensa-na-gripe-espanhola-em-1918/

25. Lemle M. Entre a solidariedade e o egoísmo, patrões escolhem defender seus próprios interesses. Blog de História, Ciências, Saúde - Manguinhos. [Internet]. 2020 [cited 2020 Apr 21]. Available from: http://www.revistahcsm.coc.fiocruz.br/ entre-a-solidariedade-e-o-egoismo-patroes-escolhem-defender-seus-proprios-interesses/

26. Mota A. Bodes expiatórios contra o mal-estar social que as doenças causam. Blog de História, Ciências, Saúde - Manguinhos. [Internet]. 2020[cited 2020 Apr 21]. Available from: http://www.revistahcsm.coc.fiocruz.br/ bodes-expiatorios-contra-o-mal-estar-social-que-as-doencas-causam/

27. Neto M, Gomes TO, Porto FR, Rafael RMR, Fonseca MHS, Nascimento J. Fake news no cenário da pandemia de COVID-19. Cogitare Enferm. 2020;25(Esp-COVID-19):5. https://doi.org/10.5380/ce.v25i0.72627 